\title{
Effect of population density on oviposition, development, and survival of Alloeocranum biannulipes (Hemiptera: Reduviidae) preying on Dinoderus porcellus (Coleoptera: Bostrichidae)
}

Yêyinou Laura Estelle Loko ${ }^{1 *} \mathbb{0}$, Joelle Toffa', Dieudonné Martin Gavoedo', Sahayaraj Kitherian², Azize Orobiyi ${ }^{1}$ and Manuele Tamò ${ }^{3}$

\begin{abstract}
Background: Alloeocranum biannulipes Montr. and Sign.(Hemiptera: Reduviidae) is a predator present in stored yam chips and a promising biological control agent against Dinoderus porcellus Lesne (Coleoptera: Bostrichidae). Numerical responses of $A$. biannulipes to different densities $(1,2,4,6$, and 8$)$ of $D$. porcellus larvae were evaluated under ambient laboratory conditions ( $\mathrm{T}^{\circ}: 25 \pm 2{ }^{\circ} \mathrm{C} ; \mathrm{RH}: 75-80 \%$; photoperiod 12:12 $\mathrm{h}(\mathrm{L} / \mathrm{D})$ ). The number of consumed prey, duration of pre-oviposition and oviposition, number of eggs laid, pre-imaginal development times and mortality rate of the predator were recorded.

Results: The results revealed that $A$. biannulipes females preying on the highest larval density of $D$. porcellus (8) presented the highest predation rate ( $4.34 \pm 0.18$ larvae/predator/day), shortest pre-oviposition period ( $11.01 \pm 0.57$ days) and the highest oviposition period (15.83 \pm 1.02 days). The daily number of eggs laid by A. biannulipes female $(\mathrm{y})$ as a function of the number of $D$. porcellus larvae consumed $(\mathrm{x})$ was modelled by the equation $y=0.158 x^{2}-0.4073 x+3.8151\left(R^{2}=0.571\right)$. The efficiency of prey conversion into eggs of $A$. biannulipes females decreased with increased prey density. The prey density did not affect the hatching rate of $A$. biannulipes eggs and the pre-imaginal development times. However, A. biannulipes nymphs fed with more (2 to 8) D. porcellus showed a significantly higher survival rate than those fed with a single larva.
\end{abstract}

Conclusions: The positive numerical response of A. biannulipes suggests that this predator could play a key role in biological control program against D. porcellus.

Keywords: A. biannulipes, Biological control, D. porcellus, Numerical response, Yam chips

\footnotetext{
*Correspondence: lokoestelle@yahoo.fr

'Laboratory of Applied Entomology, National High School of Biosciences and Applied Biotechnologies (ENSBBA), National University of Sciences, Technologies, Engineering and Mathematics of Abomey (UNSTIM), BP 14, Dassa-Zoumé, Benin

Full list of author information is available at the end of the article
}

\section{Background}

The beetle Dinoderus porcellus Lesne (1923) is the most abundant and economically important pest of stored yam chips in West Africa (Adedire \& Gbaye, 2002; Loko et al., 2013; Osuji, 1980). It causes significant economic impact because yam chips represent the main form of long-term preservation of yam tubers (Omohimi et al., 2018), which are the staple food of million people in West Africa with 
an estimated food supply quantity of $93.84 \mathrm{~kg} /$ capita/year in 2018 (FAO, 2019). D. porcellus digs galleries by feeding on the yam chips and crushes the latter into powder within a few weeks causing significant qualitative and quantitative damage (John et al., 2020). Losses caused by D. porcellus were estimated at $27.4 \%$ of yam chips after 2 months of storage (Loko et al., 2019). The use of synthetic insecticides is the main control method used by farmers to reduce $D$. porcellus populations in stored yam chips (Loko et al., 2013). However, in addition to their negative impacts on the environment, treated yam chips with synthetic insecticides have led to numerous cases of food poisoning (Adedoyin et al., 2008; Adeleke, 2009). The use of biological control agent appears to be an ecofriendly alternative method to control this storage pest.

The polyphagous predator Alloeocranum biannulipes Montr. and Sign. (1861), which coexists in the stored yam chips with $D$. porcellus appears to be an important biological control agent against this pest (Loko et al., 2013). Indeed, studies on the functional response of $A$. biannulipes feeding on larvae and pupae of $D$. porcellus at different densities (Loko et al., 2017), and a test on the suppressive effect of this predator with respect to $D$. porcellus populations showed its potential as biological agent for controlling $D$. porcellus in stored yam chips (Loko et al., 2019). The reduviid A. biannulipes has also proved to be a good candidate for biological control of Prostephanus truncatus Horn in stored cassava chips (Loko et al., 2020) and other storage pest species such as Corcyra cephalonica Stainton, Tribolium confusum Duval, and Anagasta kuehniella Zeller (Awadallah et al., 1984). However, prior to the efficient use of A. biannulipes as a biological control agent against $D$. porcellus, there is a need for information regarding its reproductive numerical response. This knowledge is crucial because it not only allows to evaluated the ability of $A$. biannulipes to reduce the abundance of $D$. porcellus in stored yam chips, but also provides baseline data for a mathematical model to calculate the number of predators needed to regulate the pest population (Parween \& Ahmad, 2015; Tangkawanit et al., 2018). In fact, the successful development and deployment of biological control programs against D. porcellus in stored yam chips using A. biannulipes will need to rely on an efficient mass rearing of this predator. However, for mass rearing of reduviids, pre-imaginal survival and development are major constraints and known as important factors in the life history of reduviids, which are strongly influence by the prey density (Grundy et al., 2000; Sahayaraj, 2002). Therefore, for the development of a cost-efficient rearing system for A. biannulipes, it is important to identify the most appropriate prey-predator ratio. The purpose of this study is to determine the numerical response of $A$. biannulipes to different levels of abundance of $D$. porcellus infesting yam chips, and assess the effect of prey density on the development and survival of $A$. biannulipes under laboratory conditions.

\section{Methods \\ Pest rearing}

Adults of D. porcellus were obtained from yam chips bought at the Dassa-Zoumé market (Collines department). The infested yam chips were gently broken with a hand mortar to collect $D$. porcellus adults. The pest was reared in cylindrical plastic boxes $(15 \mathrm{~cm}$ diameter $\times 25 \mathrm{~cm}$ high) open at one end containing dried and sterilized yam chips. The open end of the plastic boxes was covered with a muslin cloth to allow adequate ventilation and prevent the escape of insects. The plastic boxes were stored in the laboratory conditions $\left(\mathrm{T}^{\circ}: 25 \pm 2{ }^{\circ} \mathrm{C}\right.$; RH: 75-80\%; photoperiod 12:12 h (L/D)). Every two weeks the $D$. porcellus adult were removed from the rearing boxes, and the larvae were used for experiments.

\section{Predator rearing}

Adults of the predator A. biannulipes were collected in the Magoumi village (Collines department, latitude $8^{\circ} 10^{\prime} 26^{\prime \prime} \mathrm{N}$ and longitude $2^{\circ} 13^{\prime} 59^{\prime \prime} \mathrm{E}$ ) in stored rice. The collected insects were reared in plastic boxes $(15 \mathrm{~cm}$ diameter $\times 25 \mathrm{~cm}$ high) containing $500 \mathrm{~g}$ of yam chips infested by $100 \mathrm{D}$. porcellus adults of undetermined sex and age. The rearing boxes were maintained under laboratory conditions $\left(\mathrm{T}^{\circ}: 25 \pm 2{ }^{\circ} \mathrm{C}\right.$; $\mathrm{RH}$ : $75-80 \%$; photoperiod 12:12 h (L/D). Two weeks later, 20 adults of undetermined sex and age of $A$. biannulipes were added to the plastic boxes containing the infested yam chips. Every two weeks the predators were removed from the rearing boxes, and the adult progenies were used for the experiments.

\section{Prey consumption and oviposition of $A$. biannulipes in function of $D$. porcellus larvae density}

24-hours-old adults of $A$. biannulipes were placed in pairs for mating in plastic boxes $(6 \mathrm{~cm}$ diameter $\times 4 \mathrm{~cm}$ high), each containing $50 \mathrm{~g}$ of yam chips infested with D. porcellus larvae. Males and females of A. biannulipes were sexed based on their external genitalia (Loko et al., 2019). Ejection of spermatophore capsules by mated females confirmed successful copulation (Ambrose et al., 2009). After mating, the females were isolated individually in petri dishes $(100 \times 15 \mathrm{~mm})$ and starved for $24 \mathrm{~h}$. Subsequently, they were exposed to different densities $(1,2,4,6$, and 8) of D. porcellus larvae (Loko et al., 2017) supplied with yam chips. After $24 \mathrm{~h}$, the females were removed from the petri dishes and the number of eggs laid and the number of prey consumed were recorded. Observations were made for 30 consecutive days (using 
fresh prey larvae changed each day (Loko et al., 2019). Six replicates were done with five $A$. biannulipes females per replicate for each prey density. The duration of pre-oviposition and oviposition was also recorded.

The efficiency of conversion of ingested food (ECI) into egg biomass at different prey density treatments was estimated using equation:

$$
\mathrm{ECI}=\frac{\text { Number of eggs laid }}{\text { Number of prey consumed }} \times 100
$$

\section{Development and survival of $A$. biannulipes in relation to prey density}

Freshly laid A. biannulipes eggs were removed from the substrate with a fine camel hairbrush (Srikumar et al., 2014). Each egg was placed on dry cotton wool at the bottom of plastic boxes $(6 \mathrm{~cm}$ diameter $\times 4 \mathrm{~cm}$ high $)$ and kept under ambient laboratory conditions $\left(\mathrm{T}^{\circ}: 25 \pm 2{ }^{\circ} \mathrm{C}\right.$; RH: 75-80\%; photoperiod 12:12 h (L/D). A cohort of 50 eggs of different predator was established for each prey density. After egg hatching, each A. biannulipes nymph was fed individually $D$. porcellus larvae freshly supplied with yam chips every day at densities of 1, 2, 4, 6 and 8 . The post-embryonic development time of the five nymphal stages and the survival of each $A$. biannulipes developmental stages at various prey densities were recorded.

\section{Data analysis}

The relationship between $A$. biannulipes female fecundity and the efficiency of conversion of ingested food versus prey density was determined using regression analyses. Analysis of variance (ANOVA) was used to determine the difference between parameters evaluated at different prey densities, whereby the normality of the data was tested with the Shapiro-Wilk test (Shapiro \& Wilk, 1965) using IBM SPSS statistical analysis software, version 25. The means and percentages that did not show homogeneity of variances were log-transformed and arcsinetransformed, respectively, before ANOVA. The Student
Newman Keuls test was used to separate means significantly different $(p \leq 0.05)$.

\section{Results}

Oviposition of $A$. biannulipes females preying on different larval densities of $D$. porcellus

The number of $D$. porcellus larvae consumed influenced the duration of pre-oviposition and oviposition of A. biannulipes females (Table 1). Although the duration of preoviposition of $A$. biannulipes females fed with the highest prey density was shorter, it did not differ significantly $\left(p^{>} 0.05\right)$ from that of females fed with the lowest prey density. However, the length of oviposition in A. biannulipes females fed with the highest prey density was significantly $\left(p^{<} 0.05\right)$ higher from that of females fed with the lowest prey density. The increased density of $D$. porcellus larvae had a significant impact on the number of eggs laid by females of $A$. biannulipes (Table 1). At the highest larval densities of D. porcellus, the number of prey eaten and eggs laid by $A$. biannulipes females were significantly $(p \leq 0.05)$ higher than at the lowest densities (Fig. 1). The total average fecundity of A. biannulipes females peaked at $68.80 \pm 5.75$ eggs when offered the highest prey density (8). Daily oviposition of A. biannulipes females increased significantly $(p \leq 0.000)$

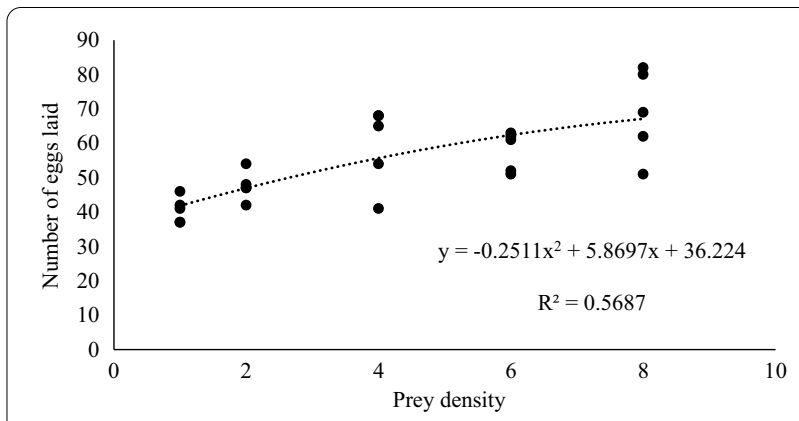

Fig. 1 Numerical response in terms of mean number of eggs laid by A. biannulipes females at increasing $D$. porcellus density

Table 1 Mean number of $D$. porcellus larvae consumed and reproduction of A. biannulipes females at increasing prey density $(N=30$ replicates for each prey density)

\begin{tabular}{lllllll}
\hline Prey density & \multicolumn{2}{l}{ Mean \pm standard error/female } & & \multicolumn{2}{l}{$\begin{array}{l}\text { Preoviposition } \\
\text { period (days) }\end{array}$} & $\begin{array}{l}\text { Oviposition } \\
\text { period (days) }\end{array}$ \\
\cline { 2 - 7 } & $\begin{array}{l}\text { Total number of } \\
\text { preys eaten }\end{array}$ & $\begin{array}{l}\text { Daily number of } \\
\text { preys eaten }\end{array}$ & Total number of eggs laid & $\begin{array}{l}\text { Daily number of } \\
\text { eggs laid }\end{array}$ & & \\
\hline 1 & $13.00 \pm 0.00 \mathrm{a}$ & $1.00 \pm 0.00 \mathrm{a}$ & $40.60 \pm 1.69 \mathrm{a}$ & $3.54 \pm 0.17 \mathrm{a}$ & $13.67 \pm 0.33 \mathrm{a}$ & $11.40 \pm 0.60 \mathrm{a}$ \\
2 & $24.60 \pm 0.74 \mathrm{~b}$ & $1.92 \pm 0.03 \mathrm{~b}$ & $47.60 \pm 1.91 \mathrm{ab}$ & $3.57 \pm 0.16 \mathrm{a}$ & $13.34 \pm 0.28 \mathrm{a}$ & $11.00 \pm 0.55 \mathrm{a}$ \\
4 & $42.60 \pm 0.69 \mathrm{c}$ & $3.32 \pm 0.12 \mathrm{c}$ & $59.20 \pm 5.22 \mathrm{bc}$ & $4.30 \pm 0.37 \mathrm{ab}$ & $11.33 \pm 0.88 \mathrm{a}$ & $12.21 \pm 0.86 \mathrm{a}$ \\
6 & $55.80 \pm 1.35 \mathrm{~d}$ & $4.29 \pm 0.15 \mathrm{~d}$ & $57.80 \pm 2.59 \mathrm{bc}$ & $4.60 \pm 0.17 \mathrm{bc}$ & $12.23 \pm 1.24 \mathrm{a}$ & $13.20 \pm 0.81 \mathrm{a}$ \\
8 & $56.80 \pm 2.81 \mathrm{~d}$ & $4.34 \pm 0.18 \mathrm{~d}$ & $68.80 \pm 5.75 \mathrm{c}$ & $5.40 \pm 0.32 \mathrm{c}$ & $11.01 \pm 0.57 \mathrm{a}$ & $15.83 \pm 1.02 \mathrm{~b}$ \\
\hline
\end{tabular}




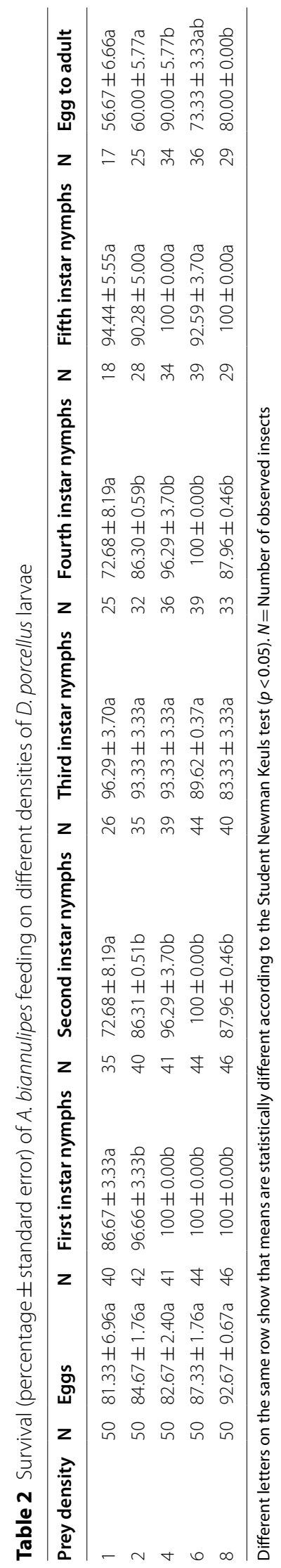




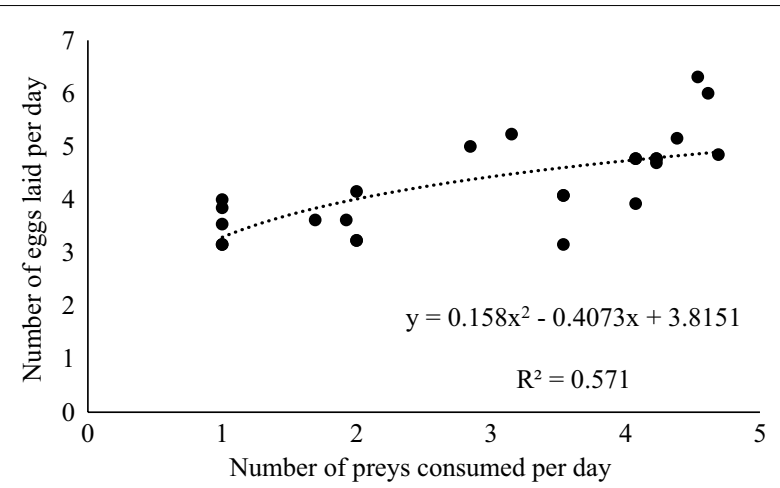

Fig. 2 Daily oviposition of A. biannulipes females as a function of the number of $D$. porcellus larvae consumed per day

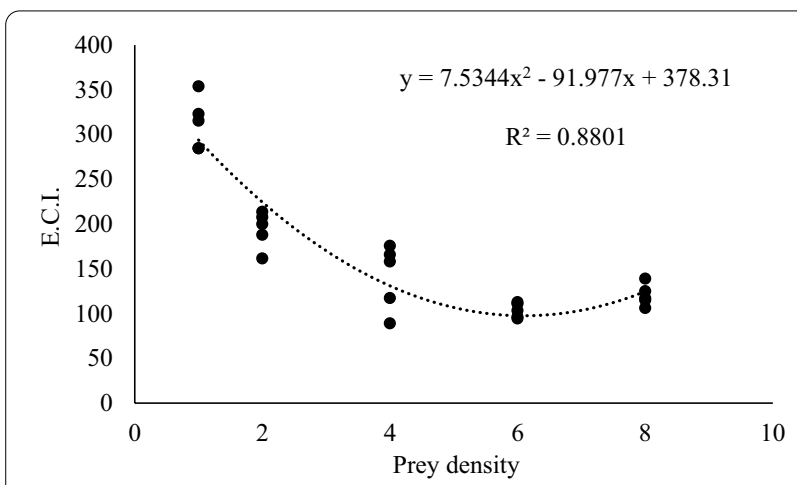

Fig. 3 Relationship between the efficiency of ingested feed conversion to egg biomass of $A$. biannulipes at increasing $D$. porcellus density

as a function of $D$. porcellus larvae consumed attaining a maximum daily oviposition rate of $5.40 \pm 0.32$ eggs for the highest prey density. There was a significant correlation between the daily number of eggs laid by an A. biannulipes female $(y)$ and the number of $D$. porcellus larvae consumed $(x)$, which can be expressed by the equation $y=0.158 x^{2}-0.4073 x+3.8151\left(R^{2}=0.571\right)$ (Fig. 2). The efficiency of food conversion into eggs (ECI) by $A$. biannulipes female decreased significantly $(p<0.001)$ with increasing prey density. However, the curve of ECI slightly increased at 8 densities of $D$. porcellus larvae (Fig. 3).

\section{Development and survival of nymph instars of $A$.} biannulipes preying on different larval densities of $D$. porcellus

The percentage of $A$. biannulipes eggs hatched was significantly high and did not vary significantly $(p \geq 0.05)$ with the prey density offered (Table 2). All first instar nymph of $A$. biannulipes fed with a density of four or more larvae survived. This survival rate was significantly $(p \leq 0.05)$ higher than that of $A$. biannulipes first instar nymph fed with a single larva. With the exception of the third and fifth nymphal instars of $A$. biannulipes, survival rates of second and fourth nymphal instars fed with a single $D$. porcellus larva were significantly $(p \leq 0.05)$ lower than those of nymphs fed with higher densities of larvae (Table 2). Egg-to-adult survival rates were significantly $(p \leq 0.05)$ higher for nymphs fed with the higher densities of $D$. porcellus larvae compared to A. biannulipes nymphs fed with 1 or 2 larvae.

Except for the fourth nymphal instar of $A$. bannulipes where the development time of nymphs fed with one larva was significantly different from nymphs fed with higher larval densities, no significant differences were observed in all other nymphal instars (Table 3). Furthermore, the development time from egg to adult showed no significant difference $(p \geq 0.05)$ according to the density of $D$. porcellus larvae.

\section{Discussion}

The predator A. biannulipes, which showed Holling's functional response type II in previous studies (Loko et al., 2017), presented a strong reproductive numerical response to increasing $D$. porcellus larvae density. As opposed to the case where A. biannulipes females were fed with larvae of P. truncatus (Loko et al., 2020), the density of $D$. porcellus larvae significantly influenced the fecundity of the predator. This difference could be explained by the quality of the prey, which is the most important factor affecting the prey-predator relationship (Aragón-Sánchez et al., 2018). Females of $A$. biannulipes preying on the highest $D$. porcellus larval densities presented the shortest preoviposition period and the highest oviposition period as observed in other reduviid predators, namely Rhynocoris marginatus (Fabricius) (Rajan \& Sreelatha, 2019) and Rhynocoris fuscipes F. (Ambrose \& Claver, 1997). The observed density-dependent numerical responses of $A$. biannulipes females suggest this predator could be an efficient biological control agent of $D$. porcellus. Predators displaying strong density-dependent reproduction rates are considered as promising biocontrol agents (Milonas et al., 2015), through their capacity to suppress pest populations before they reach damaging levels (Amiri-Jami \& Sadeghi-Namaghi, 2014).

The high proportion of prey eaten and number of eggs laid by $A$. biannulipes females at the higher prey density suggest that this predator mainly allocates ingested food for egg production. Thereby, the decreasing efficiency of prey conversion into eggs with increasing prey density is consistent with a type II functional response of A. biannulipes. This is explained by the fact that female predators invest available resources in their own maintenance only 


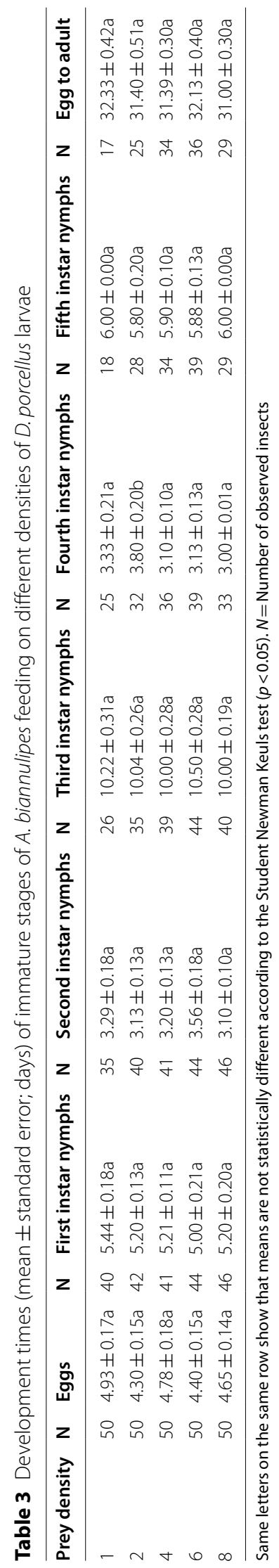


after reaching their maximum egg-laying rate (Omkar, 2004). However, at the higher $D$. porcellus larvae density, the efficient food conversion value of $A$. biannulipes females slightly increased, indicating that $A$. biannulipes females may invest part of their energy in both oviposition and predation activities. Therefore, this implies that for the mass rearing of $A$. biannulipes the optimal prey density seems to be six $D$. porcellus larvae per day to maximize offspring production.

The number of prey items offered did not influence the hatching rate of $A$. biannulipes eggs, in contrast with previous observations where $A$. biannulipes adults were fed with P. truncatus larvae (Loko et al., 2020). As reported by Sahayaraj et al. (2016), offering prey species of diverse nutritional qualities to the same predator species has resulted in different egg hatching rates. However, A. biannulipes nymphs fed with high $D$. porcellus larval densities (2-8) displayed a significantly higher survival rate than those fed with a single larva, suggesting that the nutrients provided by one prey per day are not enough for optimal survival of $A$. biannulipes nymphs. Reduced survival at low prey density was also observed in other reduviids such as $R$. fuscipes (Ambrose \& Claver, 1997), R. marginatus (Rajan \& Sreelatha, 2019) and Cosmoclopius nigroannulatus Stal (Jahnke et al., 2002).

Our results showed that $A$. biannulipes was able to complete its development at each of the five prey densities and the prey density did not affect developmental time of this predator. This suggest that one $D$. porcellus larva per day is sufficient to ensure the requirements for the pre-imaginal development of $A$. biannulipes, albeit at lower survival rates. Knowing that prey consumption by a predator depends on several biotic and abiotic factors, further studies are required to evaluate the effect of temperature on the predatory potential of A. biannulipes and the biocontrol efficiencies of the mass-produced predator against $D$. porcellus in stored yam chips under farm conditions.

\section{Conclusions}

This study revealed that $A$. biannulipes females preying on $D$. porcellus exhibited a positive, density-dependent numerical response. Prey density impacted nymph survival but not their development. We can hence conclude that for the mass rearing of $A$. biannulipes the optimal prey density seems to be six $D$. porcellus larvae per day to maximize offspring production.

\section{Abbreviation}

ECl: Efficiency of conversion of ingested food.

\section{Acknowledgements}

This research was partly supported by The World Academy of Sciences (TWAS) for the advancement of science in developing countries (Research Grant No. 14-012 RG/BIO/AF/AC_I).

\section{Authors' contributions}

LYLE participated in the study design, analysed and interpreted the data, and drafted the manuscript. TJ, GD, and OA carried out laboratory experiments. LYL, TJ, KS, and TM corrected the manuscript. All authors read and approved the final manuscript.

\section{Funding}

This research was partly supported by The World Academy of Sciences (TWAS) for the advancement of science in developing countries; Research Grant No. 14-012 RG/BIO/AF/AC_I.

\section{Availability of data and materials}

Raw and treated data generated during study are available from the corresponding author on reasonable request.

\section{Declarations}

Ethics approval and consent to participate

Not applicable.

\section{Consent for publication}

Not applicable.

\section{Competing interests}

The authors have no conflicts of interest to declare that are relevant to the content of this article.

\section{Author details}

'Laboratory of Applied Entomology, National High School of Biosciences and Applied Biotechnologies (ENSBBA), National University of Sciences, Technologies, Engineering and Mathematics of Abomey (UNSTIM), BP 14, Dassa-Zoumé, Benin. ${ }^{2}$ Department of Zoology, Crop Protection Research Centre, St. Xavier's College, Palayamkottai, Tirunelveli, Tamil Nadu 627002, India. ${ }^{3}$ International Institute of Tropical Agriculture, 08 BP 0932, Cotonou, Benin.

Received: 3 August 2021 Accepted: 8 February 2022

Published online: 19 February 2022

\section{References}

Adedire, C. O., \& Gbaye, O. A. (2002). Seasonal Prevalence and life history of the Yam Beetle, Dinoderus porcellus (Lesne) (Coleoptera: Bostrichidae). Nigerian Journal of Experimental and Applied Biology, 3, 323-329.

Adedoyin, O. T., Ojuawo, A., Adesiyun, O. O., Mark, F., \& Anigilage, E. A. (2008). Poisoning due to the yam flour consumption in five families in llorin, Central Nigeria. West African Journal of Medicine, 27, 41-43.

Adeleke, S. I. (2009). Food poisoning due to yam flour consumption in Kano (Northwest) Nigeria. The Online Journal of Health and Allied Sciences, 8, 10.

Ambrose, D. P., \& Claver, M. A. (1997). Functional and numerical responses of the reduviid predator, Rhynocoris fuscipes $F$ (Het, Reduviidae) to cotton leaf worm Spodoptera litura F (Lep, Noctuidae). Journal of Applied Entomology, 121(1-5), 331-336. https://doi.org/10.1111/j.1439-0418.1997. tb01415.x

Ambrose, D. P., Rajan, S. J., Nagarajan, K., \& Krishnan, S. S. (2009). Biology, behaviour and functional response of Sphedanolestes variabilis Distant (Insecta: Hemiptera: Reduviidae: Harpactorinae), a potential predator of lepidopteran pests. Entomologia Croatica, 13, 33-44.

Amiri-Jami, A. R., \& Sadeghi-Namaghi, H. (2014). Responses of Episyrphus balteatus DeGeer (Diptera: Syrphidae) in relation to prey density and predator size. Journal of Asia-Pacific Entomology, 17(3), 207-211. https:// doi.org/10.1016/j.aspen.2014.01.007

Aragón-Sánchez, M., Román-Fernández, L. R., Martínez-García, H., AragónGarcía, A., Pérez-Moreno, I., \& Marco-Mancebón, V. S. (2018). Rate of consumption, biological parameters, and population growth capacity of Orius laevigatus fed on Spodoptera exigua. BioControl, 63, 785-794. https:// doi.org/10.1007/s10526-018-9906-4

Awadallah, K. T., Tawfik, M. F. S., \& Abdellah, M. M. H. (1984). Suppression effect of the reduviid predator, Allaeocranum biannulipes (Montr et Sign) on 
populations of some stored-product insect pests. Journal of Applied Entomology, 97, 249-253. https://doi.org/10.1111/j.1439-0418.1984.tb03745.x

FAO. (2019). (Food and Agricultural Organization). Food and Agricultural Organization of the United Nations. Retrieved March 21, 2021, from http://www. faostat.org

Grundy, P. R., Maelzer, D. A., Bruce, A., \& Hassan, E. A. (2000). mass-rearing method for the assassin bug Pristhesancus plagipennis (Hemiptera: Reduviidae). Biological Control, 18, 243-250. https://doi.org/10.1006/bcon. 2000.0832

Jahnke, S. M., Redaelli, L. R., \& Diefenbach, L. M. G. (2002). Population dynamics of Cosmoclopius nigroannulatus Stal (Hemiptera, Reduviidae) in tobacco culture. Brazilian Journal of Biology, 62(4), 819-826. https://doi.org/10. 1590/S1519-69842002000500011

John, W. C., Richard, K., Ishaya, M., Olori-Oke, O., Kyaharle, B. S., \& Chomini, M. S. (2020). Anti-reproductive efficacy of Adansonia digitata Powder against Dinoderus porcellus Associated with Yam Chips Spoilage in Jos Metropolis Nigeria. JASEM, 25(2), 257-260. https://doi.org/10.4314/jasem.v25i2.19

Loko, Y. L., Dansi, A., Tamo, M., Bokonon-Ganta, A. H., Assogba, P., Dansi, M., Vodouhè, R., Akoegninou, A., \& Sanni, A. (2013). Storage insects on yam chips and their traditional management in Northern Benin. Science World Journal, 11, 484-536. https://doi.org/10.1155/2013/484536

Loko, Y. L., Djagoun, A. D., Dannon, E. A., Datinon, B., Dansi, A., Thomas-Odjo, A. A., \& Tamo, M. (2017). Functional response of the predators Alloeocranum biannulipes (Hemiptera: Reduviidae) and Teretrius nigrescens (Coleoptera: Histeridae) feeding on Dinoderus porcellus (Coleoptera: Bostrichidae) infesting yam chips. Environmental Entomology, 46(1), 84-91. https://doi. org/10.1093/ee/nvw156

Loko, Y. L. E., Gavoedo, D. M., Toffa, J., Orobiyi, A., Thomas-Odjo, A., \& Tamò, M. (2019). Life table of the predator Alloeocranum biannulipes Montrouzier and Signoret (Hemiptera: Reduviidae) and a test of its ability to suppress populations of Dinoderus porcellus Lesne (Coleoptera: Bostrichidae) in stored yam chips. Biological Control, 130, 60-69. https://doi.org/10.1016/j. biocontrol.2018.12.011

Loko, Y. L. E., Onzo, A., Datinon, B., Akogninou, L., Toffa, J., Dannon, E., \&Tamo, A. (2020). Population dynamics of the predator Alloeocranum biannulipes Montrouzier and Signoret (Hemiptera: Reduviidae) feeding on the larger grain borer, Prostephanus truncatus (Horn) (Coleoptera: Bostrichidae), infesting cassava chips. Egyptian Journal of Biological Pest Control, 30, 35. https://doi.org/10.1186/s41938-020-00240-1

Milonas, P. G., Partsinevelos, G., \& Martinou, A. F. (2015). Patch assessment for oviposition by a predator: The effect of prey density and prey oviposition period. Journal of Insect Behavior, 28(5), 535-543. https://doi.org/10.1007/ s10905-015-9523-3

Omkar, P. A. (2004). Functional and numerical responses of Propylea dissecto (Mulsant) (Coleoptera: Coccinellidae). Journal of Applied Entomology, 128, 140-146. https://doi.org/10.1111/j.1439-0418.2004.00824.x

Omohimi, C. I., Piccirillo, C., Roriz, M., Vasconcelos, M. W., Sanni, L. O., Tomlins, K., Pintado, M. M., \& Abayomi, L. A. (2018). Study of the proximate and mineral composition of different Nigerian yam chips, flakes and flours. Journal of Food Science Technology, 55, 42-51. https://doi.org/10.1007/ s13197-017-2761-y

Osuji, F. N. C. (1980). Observations on beetles attacking dried yams and yam flour from three Nigerian markets. Tropical Stored Products Information, 39, 35-38.

Parween, N., \& Ahmad, M. E. (2015). Numerical response of Lipolexis oregmae (Hymenoptera: Aphidiinae) against Aphis craccivora (Hemiptera: Aphididae). European Scientific Journal, 11(24), 277-286.

Rajan, J. S., \& Sreelatha, E. (2019). Numerical Response of Rhynocoris marginatus (Fabricius) (Hemiptera: Reduviidae) to Two Pests of Redgram (Cajanus cajan (L.) Millsp.). Bulletin of Environment, Pharmacology and Life Sciences, $8(4), 65-68$

Sahayaraj, K. (2002). Small-scale laboratory rearing of a reduviid predator, Rhynocoris marginatus Fab (Hemiptera: Reduviidae) on Corcyra cephalonica Stainton larvae by larval card method. Journal of Central European Agriculture, 3, 137-148.

Sahayaraj, K., Kumar, M. S., \& Enkegaard, A. (2016). Response of the reduviid bug, Rhynocoris marginatus (Heteroptera: Reduviidae) to six different species of cotton pests. European Journal of Entomology, 113, 29-36.

Shapiro, S. S., \& Wilk, M. B. (1965). An analysis of variance test for normality (complete samples). Biometrika, 65(3/4), 591-611. https://doi.org/10. 2307/2333709
Srikumar, K. K., Bhat, P. S., Raviprasad, T. N., Vanitha, K., Saroj, P. L., \& Ambrose, D. P. (2014). Biology and Behavior of Six Species of Reduviids (Hemiptera: Reduviidae: Harpactorinae) in a Cashew Ecosystem. Journal of Agricultural and Urban Entomology, 30, 65-81. https://doi.org/10.3954/JAUE14-14.1

Tangkawanit, U., Hinmo, N., \& Khlibsuwan, W. (2018). Numerical Response of Cyrtorhinus lividipennis (Hemiptera: Miridae) to Nilaparvata lugens (Hemiptera: Delphacidae). Journal of Entomology Science, 53(2), 171-179. https:// doi.org/10.18474/jes17-42.1

\section{Publisher's Note}

Springer Nature remains neutral with regard to jurisdictional claims in published maps and institutional affiliations.

\section{Submit your manuscript to a SpringerOpen ${ }^{\circ}$ journal and benefit from:}

- Convenient online submission

- Rigorous peer review

- Open access: articles freely available online

- High visibility within the field

- Retaining the copyright to your article

Submit your next manuscript at $\boldsymbol{\nabla}$ springeropen.com 